\title{
PENGEMBANGAN LKPD BERBASIS DISCOVERY LEARNING PADA MATERI FLUIDA DINAMIS
}

\author{
Evelyne Mega Patricia*, I Dewa Putu Nyeneng, Ismu Wahyudi \\ FKIP Universitas Lampung, Jl. Prof. Dr. Soemantri Brojonegoro No.1 \\ *email: evelynemustamu7@gmail.com
}

Received: 28 Mei 2018 Accepted: 4 Juni 2018 Online Published: 4 Juni 2018

\begin{abstract}
Discovery learning provides an opportunity for students to be active during the learning process. Learning process using LKPD can guide students to learn independently, so that learning becomes centered on students. This research aims to a) produce valid LKPD based discovery learning on dynamic fluid material, b) to know its attractiveness, usefulness, and easy to use, c) to know the effectiveness of the product. The research design uses the ADDIE model, with stages: analysis, design, development, implementation, and evaluation. The result of the tested the product showed that had a) validated by an expert and proper to used, b) interested (3,23); useful (3,36); and easy to use (3,30), and 3) The product was effectively tested to use in teaching learning with percentage $75,68 \%$.
\end{abstract}

Keywords: discovery learning, dynamic fluid, student worksheet, development

\begin{abstract}
Abstrak: Discovery learning memberikan kesempatan bagi peserta didik untuk aktif selama proses pembelajaran berlangsung. Proses pembelajaran menggunakan LKPD dapat menuntun peserta didik untuk belajar secara mandiri, sehingga pembelajaran menjadi berpusat pada peserta didik. Penelitian ini bertujuan untuk a) menghasilkan LKPD berbasis discovery learning yang valid pada materi fluida dinamis, b) mengetahui kemenarikan, kemanfaatan, dan kemudahgunaannya, c) mengetahui keefektifan produk. Desain penelitian menggunakan model ADDIE, dengan tahap-tahap: analisis, desain, pengembangan, implementasi, dan evaluasi. Hasil dari uji produk menunjukkan bahwa a) produk tervalidasi ahli dan layak digunakan, b) menarik $(3,23)$; sangat bermanfaat $(3,36)$; dan sangat mudah digunakan $(3,30)$, dan c) produk teruji efektif digunakan dalam pembelajaran dengan persentase mencapai $75,68 \%$.
\end{abstract}

Kata kunci: discovery learning, fluida dinamis, LKPD, pengembangan 


\section{PENDAHULUAN}

Fisika merupakan salah satu cabang sains yang berperan besar dalam menunjang ilmu pengetahuan dan teknologi. Sari dan Harjono (2016) menyatakan bahwa fisika dipandang sebagai pengetahuan yang berupa fakta, konsep, prinsip, dan teori, serta fisika merupakan proses ilmiah seperti melakukan pengukuran, percobaan, dan diskusi serta melibatkan peserta didik secara langsung dalam pembelajaran agar membantu mereka memahami konsep-konsep yang ada. Untuk itu, paradigma pembelajaran fisika harus disesuaikan dengan kurikulum 2013 yang memposisikan peserta didik sebagai pusat belajar, di mana peserta didik secara aktif membangun konsep pembelajaran melalui pendekatan ilmiah (Kemendikbud, 2013).

Penelitian pendahuluan yang telah dilakukan di SMA Negeri 8 Bandar Lampung, menunjukkan bahwa metode ceramah dan pemberian latihan soal masih dominan guru terapkan dalam pembelajaran fisika, selain itu selama pembelajaran yang telah berlangsung tidak dilaksanakan kegiatan percobaan, artinya peserta didik tidak menemukan konsep fisika melalui proses mentalnya sendiri. Penggunaan metode dan media tersebut dianggap menjadi faktor yang mempengaruhi $89,28 \%$ peserta didik masih mengalami kesulitan dalam mempelajari materi fluida dinamis.

Materi fluida dinamis tidak hanya membekali peserta didik dengan pengetahuan konsep, tetapi juga keterampilan ilmiah melalui kegiatan yang menerapkan prinsip fluida dinamis. Kompetensi dasar berdasarkan silabus fisika SMA kelas XI kurikulum 2013 revisi tahun 2016 untuk materi pokok fluida dinamis, yaitu KD 3.4 menerapkan prinsip fluida dinamis dalam teknologi, serta KD 4.4 membuat dan menguji proyek sederhana yang menerapkan prinsip dinamika fluida, dan makna fisisnya (Kemendikbud, 2016)

Sirait (2017) menyatakan bahwa proses pembelajaran sekarang ini menggunakan pendekatan, strategi, dan metode pembelajaran yang mengacu pada konsep kontruktivisme yang mendorong dan menghargai usaha belajar peserta didik dengan proses discovery dan inkuiri learning, sehingga peserta didik terlibat langsung dengan masalah, dan tertantang untuk belajar menyelesaikan berbagai masalah yang relevan dengan kehidupan mereka.

Discovery learning merupakan pembelajaran yang dilakukan dengan kegiatan pengamatan atau percobaan, untuk menemukan konsep berdasarkan serangkaian data atau informasi yang yang telah diperoleh, selama proses pembelajaran peserta didik secara mandiri dan aktif dapat menyelesaikan permasalahan, sehingga mengajarkan kemampuan berpikir logis, analitis, dan sistematis pada peserta didik (Wahyudi dan Siswanti, 2015).

Menurut Rahmawati dkk. (2012), discovery learning merupakan model pembelajaran yang dapat membimbing dan memotivasi peserta didik untuk mengeksplorasi informasi-informasi dan konsep sehingga mengkonstruksi ide-ide baru, mengidentifikasi suatu hubungan baru, dan menciptakan cara berpikir dan berperilaku melalui tahapan stimulasi, identifikasi masalah, pengumpulan data, pengolahan data, pembuktian, dan menarik kesimpulan.

Model discovery learning cocok untuk pembelajaran fluida dinamis, karena discovery learning dapat meningkatkan aktivitas peserta didik, mendorong peserta didik berpikir intuisi dan merumuskan hipotesis sendiri, memungkinkan peserta didik dapat belajar dengan memanfaatkan berbagai 
jenis sumber belajar, serta dapat mengembangkan bakat dan kecakapan individu, melalui proses tersebut peserta didik memperoleh pengetahuan yang bersifat sangat pribadi sehingga dapat kokoh tertinggal dalam diri peserta didik. Anggapan tersebut diperkuat dengan hasil penelitian yang dilakukan oleh Wahjudi (2015), menunjukkan bahwa model discovery learning memiliki pengaruh yang signifikan terhadap motivasi belajar dan hasil belajar IPA peserta didik di SMP Kalianget, yaitu meningkatkan aktivitas peserta didik dalam belajar baik secara individu maupun berkelompok, serta meningkatkan hasil belajar peserta didik.

Pelaksanaan pembelajaran tidak hanya ditunjang dari aspek kesiapan guru saja, tetapi juga kesiapan peserta didik dan memerlukan media yang dapat digunakan peserta didik secara mandiri. Penerapan media pembelajaran di sekolah dapat meningkatkan efektivitas dan efisiensi proses belajar (Naz dan Akbar, 2008). Pemilihan metode dan media pembelajaran yang kurang tepat serta pengelolaan kegiatan pembelajaran yang belum dapat membangkitkan motivasi belajar peserta didik secara optimal, merupakan penyebab rendahnya hasil belajar (Gumrowi, 2016).

Wahyuni dan Maureen (2010) menjelaskan bahwa media pembelajaran adalah segala sesuatu yang dapat digunakan untuk mempermudah penyampaian pesan yang dilakukan dari pengirim ke penerima pesan sehingga dapat merangsang pikiran, perasaan, perhatian, dan minat belajar peserta didik sedemikian rupa sehingga proses belajar terjadi dalam rangka mencapai tujuan pembelajaran secara efektif

Salah satu media pembelajaran yang digunakan secara mandiri yaitu Lembar Kerja Peserta Didik (LKPD).
LKPD merupakan lembaran-lembaran yang berisi petunjuk langkah-langkah yang harus dikerjakan peserta didk, di mana peserta didik mengerjakan sesuatu terkait dengan apa yang sedang dipelajarinya. Sesuatu yang dipelajari sangat beragam, seperti melakukan percobaan, mengidentifikasi bagianbagian, membuat tabel, melakukan pengamatan, menggunakan alat/bahan pengamatan dan menuliskan atau menggambar hasil pengamatannya, melakukan pengukuran dan mencatat data hasil pengukurannya, menganalisis data hasil pengukuran, serta menarik kesimpulan (Suyanto dkk., 2011).

Mayasari dkk. (2015) menyatakan masih banyak sekolah memiliki LKPD yang hanya berisi soal-soal, sehingga peserta didik akan terbebani karena harus menjawab soal-soal bukan memahami materi, berdasarkan hal tersebut maka perlu adanya LKPD eksperimen, selain itu hasil penelitian Wijayanti (2016) menunjukkan bahwa LKPD penemuan terbimbing yang telah dikembangkan dengan berorientasi kurikulum 2013 dinyatakan efektif untuk digunakan dalam pembelajaran. Hasil tersebut didukung juga dengan temuan penelitian Khoiriyah dkk. (2013) yang menunjukkan bahwa LKPD discovery mampu memandu peserta didik dalam melakukan percobaan secara mandiri sehingga keterampilan peserta didik dalam melakukan percobaan menjadi baik dan memperoleh hasil belajar yang sangat baik. Selain itu, LKPD juga dapat membantu meningkatkan kemampuan argumentasi sains pada peserta didik (Kusdiningsih dkk., 2016).

Usaha untuk mengarahkan peserta didik menemukan konsep-konsep fluida dinamis melalui aktivitasnya sendiri dalam proses pembelajaran penemuan (discovery), yaitu melakukan penelitian pengembangan untuk menghasilkan 
produk berupa LKPD berbasis discovery learning pada materi fluida dinamis yang valid.untuk mengetahui kemenarikan, kemanfaatan, kemudahgunaan, dan keefektifan LKPD berbasis discovery learning pada materi fluida dinamis.

\section{METODE PENELITIAN}

Penelitian dilakukan dengan menggunakan metode penelitian pengembangan (Research and Development). Pengembangan yang dilakukan merupakan pengembangan LKPD berbasis discovery learning pada materi fluida dinamis.

Model penelitian ini menggunakan prosedur pengembangan $A D D I E$, yang dimulai dari tahap pertama melakukan studi pendahuluan, pada tahap ini dilakukan analisis kebutuhan melalui penyebaran angket kepada guru fisika dan peserta didik. Tahap kedua yaitu mendesain produk, pada tahap ini dilakukan pembuatan perencanaan produk berupa desain hipotetik, desain tersebut dibuat dengan memperhatikan hasil studi pendahuluan. Tahap ketiga mengembangkan LKPD berbasis discovery learning pada materi fluida dinamis dilanjutkan dengan validasi oleh ahli desain dan ahli materi. Hasil uji memperoleh gambaran mengenai komponen produk yang harus direvisi.

Analisis angket uji validasi ahli memiliki empat pilihan jawaban yang sesuai dengan konten pertanyaan, yaitu: "Sangat Baik" dengan skor "4", "Baik" dengan skor "3", "Kurang Baik" dengan skor "2", dan "Tidak Baik" dengan skor 1. Skor yang diterima oleh para ahli dikalkulasi untuk mengetahui persentase kelayakan produk.

Kriteria penilaian persentase kelayakan (P) dapat diperoleh dari perbandingan skor aspek yang diperoleh (f) dengan skor maksimum aspek (n) dikali 100\%. Setelah mendapatkan persentase penilaian, maka dapat dikonversikan menjadi nilai kualitas yang dapat dilihat pada Tabel 1 .

Tabel 1. Kriteria Kelayakan Materi dan Desain

\begin{tabular}{clc}
\hline No & Kelayakan $(\%)$ & Kriteria \\
\hline 1 & $76 \% \leq \mathrm{P} \leq 100 \%$ & Sangat Baik \\
2 & $51 \% \leq \mathrm{P} \leq 75 \%$ & Baik \\
3 & $26 \% \leq \mathrm{P} \leq 50 \%$ & Kurang Baik \\
4 & $0 \% \leq \mathrm{P} \leq 25 \%$ & Tidak Baik \\
\hline
\end{tabular}

(Suradnya 2016: 71)

Produk yang telah direvisi sudah menjadikan produk valid, kemudian pada tahap keempat dilakukan pengimplementasian produk LKPD berbasis discovery learning pada materi fluida dinamis dalam pembelajaran fluida dinamis di SMA kelas XI IPA tahun ajaran 2017/2018 dengan satu kelas sampel. Uji coba dilakukan untuk melihat kemenarikan, kemanfaatan, kemudahgunaan, dan keefektifan dari LKPD yang telah dikembangkan.

Kemenarikan, kemanfaatan, dan kemudahgunaan LKPD yang telah dikembangkan dapat dilihat dari hasil penyebaran angket pada peserta didik setelah dilakukannya pembelajaran menggunakan LKPD berbasis discovery learning pada materi fluida dinamis, sementara untuk keefektifan produk yang dikembangkan dapat dilihat dari hasil pemberian pretest dan posttest atau dilihat $N$-Gain.

Analisis angket respon peserta didik untuk melihat kemenarikan, kemanfaatan, dan kemudahgunaan produk memiliki empat pilihan jawaban. Skor penilaian dari tiap pilihan jawaban dapat dilihat dalam tabel 2.

Penilaian total dapat dicari dengan perhitungan perbandingan jumlah skor yang diperoleh dengan jumlah nilai total skor tertinggi dikalikan empat. 
Tabel 2. Skor Penilaian terhadap Pilihan Jawaban

\begin{tabular}{llll}
\hline & \multicolumn{2}{c}{ Pilihan Jawaban pada } & \multirow{2}{*}{ Skor } \\
\cline { 1 - 3 } Uji Kemenarikan & $\begin{array}{l}\text { Uji } \\
\text { kemanfaatan }\end{array}$ & Uji kemudahgunaan & \\
\hline Sangat Menarik & Sangat Bermanfaat & Sangat Mudah & 4 \\
Menarik & Bermanfaat & Mudah & 3 \\
Kurang Menarik & Kurang Bermanfaat & Kurang Mudah & 2 \\
Tidak Menarik & Tidak Bermanfaat & Tidak Mudah & 1 \\
\hline
\end{tabular}

Tabel 3. Konversi Skor menjadi Penyataan Nilai Kualitas

\begin{tabular}{clll}
\hline Rentang Skor & Kemenarikan & Kemanfaatan & Kemudahgunaan \\
\hline $3,26-4,00$ & Sangat Menarik & Sangat Bermanfaat & Sangat Mudah \\
$2,51-3,25$ & Menarik & Bermanfaat & Mudah \\
$1,76-2,50$ & Kurang Menarik & Kurang Bermanfaat & Kurang Mudah \\
$1,01-1,75$ & Tidak Menarik & Tidak Bermanfaat & Tidak Mudah \\
\hline
\end{tabular}

Skor penilaian kemudian dicari rata-ratanya dari sejumlah sampel uji coba dan dikonversikan ke pernyataan nilai kualitas. Pengkonversian skor dapat dilihat pada tabel 3 .

Tahap terakhir yaitu mengevaluasi proses pembelajaran menggunakan LKPD yang telah dikembangkan.

Analisis data uji keefektifan produk menggunakan uji $\mathrm{N}$-Gain. Skor Gain yaitu perbandingan gain aktual dengan gain maksimum.

Jika $\mathrm{g}>0,7$ dikategorikan tinggi, jika $0,3 \leq \mathrm{g} \leq 0,7$ dikategorikan sedang, dan jika $\mathrm{g}<0,3$ dikategorikan rendah. Apabila $70 \% \mathrm{~N}$-Gain termasuk dalam kategori sedang hingga tinggi, maka LKPD yang dikembangkan efektif digunakan sebagai media pembelajaran.

\section{HASIL DAN PEMBAHASAN Hasil Penelitian}

Pengembangan LKPD berbasis discovery learning pada materi fluida dinamis sebagai media pembelajaran, dimulai dengan melakukan analisis kebutuhan. Analisis dilakukan pada angket yang telah diisi oleh guru dan peserta didik pada studi pendahuluan. Hasil analisis ini memperoleh keadaan rill proses pembelajaran yang mendukung untuk dikembangkannya LKPD berbasis discovery learning pada materi fluida dinamis, di mana kenyataan di lapangan menunjukkan bahwa guru masih dominan dalam pembelajaran sementara kurikulum 2013 menuntut peserta didik aktif, selain itu belum tersedianya LKPD yang menuntun peserta didik menemukan konsep fluida dinamis melalui pembelajaran discovery. Guru fisika dan 82,86\% peserta didik menyatakan perlu dikembangkan LKPD berbasis discovery learning untuk membantu mempelajari materi fluida dinamis.

Desain hipotetik LKPD disesuaikan dengan kurikulum 2013 revisi 2016. Format LKPD berbasis discovery learning pada materi fluida dinamis, meliputi bagian pembuka, isi, dan penutup. Bagian pembuka terdiri dari cover, kata pengantar, daftar isi, kompetensis inti, kompetensi dasar, dan petunjuk penggunaan. Bagian isi meliputi kegiatan pembelajaran yang terdiri dari tiga topik, pertemuan pertama berisi kegiatan percobaan mengenai Asas Kontinuitas, pertemuan 
kedua berisi kegiatan percobaan mengenai Asas Bernoulli, dan pertemuan ketiga berisi kegiatan membuat produk penerapan Asas Bernoulli.

Indikator dan tujuan pembelajaran yang akan dicapai ditunjukkan pada setiap kegiatan. Kegiatan pembelajaran dalam LKPD yang dikembangkan ini disusun sesuai dengan tahap discovery learning, yaitu stimulasi, identifikasi masalah, pengumpulan data, pengolahan data, verifikasi, dan menarik kesimpulan. Bagian penutup meliputi daftar pustaka dan glosarium.

Tahap pengembangan merupakan tahap merealisasikan desain produk menjadi produk nyata yang dikembangan. Uji ahli dilakukan pada produk awal untuk memvalidasi desain dan materi LKPD yang dikembangkan. Pada uji ahli, validator memberikan beberapa saran perbaikan sebagai berikut: 1) memperbaiki tata letak tulisan judul LKPD pada cover, 2) menambahkan gambar tentang contoh penerapan Asas Bernoulli, 3) memperbaiki gambar menjadi proporsional dan diberi keterangan gambar, 4) memberikan keterangan rumus yang digunakan dalam tabel pengematan, 5) menyusun indikator sesuai urutan kata kerja operasional untuk ranah kognitif dan psikomotor, dan 6) meletakkan indikator pembelajaran pada awalan kegiatan sehingga guru dan peserta didik memahami indikator yang dicapai setiap pertemuan.

Produk awal telah direvisi berdasarkan saran perbaikan dari para ahli, sehingga didapatkan produk utama yang layak diujicobakan dalam pembelajaran SMA. Hasil uji validasi LKPD dapat dilihat pada tabel 4.

Tahap implementasi dilakukan di SMA Negeri 8 Bandarlampung dengan satu kelas sampel. Peserta didik diberikan pretest sebelum diberi perlakuan pembelajaran menggunakan LKPD berbasis discovery learning pada materi fluida dinamis. Setelah perlakuan pembelajaran diberikan, peserta didik diberikan posttest dan angket respon peserta didik untuk menyatakan apakah LKPD sudah menarik, bermanfaat, dan mudah digunakan. Hasil penilaian peserta didik dapat dilihat pada table 5 . Pemberian pretest dan posttest memperoleh skor gain yang menunjukkan apakah ada peningkatan hasil belajar peserta didik untuk mengetahui keefektifan LKPD yang telah dikembangkan. Hasil uji keefektifan LKPD dapat dilihat pada tabel 6 .

Tabel 4. Hasil Uji Validasi LKPD Berbasis Discovery Learning oleh Ahli

\begin{tabular}{cccc}
\hline No & Validator & Kelayakan $(\%)$ & Kriteria \\
\hline 1 & Ahli Desain 1 & 94,44 & Sangat Baik \\
2 & Ahli Desain 2 & 97,22 & Sangat Baik \\
3 & Ahli Materi 1 & 93,75 & Sangat Baik \\
4 & Ahli Materi 2 & 93,75 & Sangat Baik \\
\hline & Rerata Persentase & 94,79 & Sangat Baik \\
\hline
\end{tabular}


Tabel 5. Hasil Penilaian Peserta Didik dalam Uji Coba

\begin{tabular}{clcl}
\hline No & Jenis Uji & Rata-Rata Skor & Pernyataan Kualitas \\
\hline 1 & Kemenarikan & 3,23 & Menarik \\
2 & Kemanfaatan & 3,36 & Sangat Bermanfaat \\
3 & Kemudahgunaan & 3,30 & Sangat mudah \\
\hline
\end{tabular}

Tabel 6. Hasil Uji Kefektifan LKPD

\begin{tabular}{ccccc}
\hline No & Rentang & Kategori & Frekuensi & Persentase (\%) \\
& Gain $(\mathrm{g})$ & & & \\
\hline 1 & $\mathrm{~g}<0,3$ & Rendah & 9 & 24,32 \\
2 & $0,3 \leq \mathrm{g} \leq 0,7$ & Sedang & 25 & 67,57 \\
3 & $\mathrm{~g}>0,7$ & Tinggi & 3 & 8,11 \\
\hline
\end{tabular}

$N$-Gain peserta didik yang termasuk dalam klasifikasi Gain Ternormalisasi sedang hingga tinggi mencapai $75,68 \%$ peserta didik. Ratarata perhitungan Gain mencapai skor 0,38 dengan kategori sedang, menunjukkan adanya peningkatan hasil belajar peserta didik, sehingga LKPD yang dikembangkan efektif digunakan dalam pembelajaran. Hasil penilaian respon peserta didik dalam uji coba menunjukkan bahwa LKPD berbasis discovery learning pada materi fluida dinamis dinyatakan menarik, sangat bermanfaat, sangat mudah digunakan, dan efektif sebagai media pembelajaran.

Evaluasi dilakukan setelah tahap implementasi, pada tahap ini tidak ada saran dan masukan dari guru fisika maupun peserta didik selama uji coba lapangan, LKPD yang dikembangkan sudah baik. Berdasarkan hasil evaluasi yang dilakukan secara mandiri selama proses penelitian menunjukkan bahwa pembelajaran menggunakan LKPD berbasis discovery learning pada materi fluida dinamis ini membutuhkan waktu yang lama sehingga guru harus mengantisipasi dengan tetap melakukan bimbingan selama proses pembelajaran dan peserta didik harus dikelompokkan secara heterogen berdasarkan tingkat keaktifan dan kecerdasan peserta didik.

Keunggulan LKPD berbasis discovery learning pada materi fluida dinamis ini dapat menuntun peserta didik terlibat aktif dalam pembelajaran melalui kegiatan percobaan secara mandiri, sehingga memungkinkan peserta didik tuntuk lebih banyak mengeksplorasi informasi-informasi dari berbagai sumber belajar, selain itu menimbulkan kerjasama dan interaksi antar peserta didik.

\section{Pembahasan}

LKPD berbasis discovery learning pada materi fluida dinamis yang dikembangkan telah memenuhi empat kriteria media pembelajaran ideal yang diungkapkan oleh Johar, dkk. (2014), yaitu relevan, menarik, bermanfaat, mudah digunakan. tersebut.

LKPD berbasis discovery learning pada materi fluida dinamis telah valid dengan nilai kevalidan 94,79\% (kriteria sangat baik) dan memenuhi persyaratan pembuatan LKPD yang baik menurut Widjajanti (2008), yaitu LKPD harus 
memiliki syarat didaktik, syarat konstruksi, dan syarat teknik, serta sesuai dengan struktur LKPD secara umum menurut Katriani (2014), yaitu LKPD terdapat judul kegiatan, tema, kelas, semester, tujuan pembelajaran yang sesuai $\mathrm{KD}$, alat dan bahan, prosedur kerja, tabel data, dan bahan diskusi. LKPD yang dikembangkan diberikan rekomendasi layak digunakan dalam pembelajaran SMA.

LKPD berbasis discovery learning pada materi fluida dinamis dinyatakan menarik dengan skor kemenarikan 3,23. LKPD menarik dari segi tampilan maupun isi, desain yang berwarna menumbuhkan minat baca peserta didik sehingga peserta didik tertarik dan perhatian pada proses pembelajaran, hal tersebut sesuai dengan pendapat Irmayani, dkk. (2014) yang menyatakan bahwa minat belajar yang tumbuh dapat menggerakkan rasa ketertarikan pada sesuatu, sehingga minat mempunyai pengaruh yang besar terhadap pelajaran dan dapat merangsang peserta didik untuk menambah kegiatan belajar.

Orientasi masalah dan tahapan kegiatan pembelajaran yang disajikan sesuai dengan model discovery learning, menggiring peserta didik mengalami kegiatan langsung untuk menemukan konsep, seperti melakukan percobaan dan mengeksplorasi informasi-informasi, hal itu membuat peserta didik semangat dan terlibat aktif dalam proses pembelajaran. Peserta didik menyatakan sangat senang dengan pembelajaran discovery karena tidak membosankan ketika belajar, walaupun peserta didik masih merasa baru terhadap suasana belajar tersebut, mereka cenderung untuk tetap belajar. Menurut Sintia, dkk. (2015), alasan yang membuat LKPD dengan model discovery learning terlihat menarik dan berbeda dari LKPD yang biasa digunakan yakni terletak pada tahapan kegiatan pembelajaran discovery yang disajikan melalui pendekatan saintifik sehingga menjadikan peserta didik lebih berperan aktif dalam pembelajaran melalui aktivitas penemuan.

Tingginya skor kemenarikan yang diperoleh, merupakan dampak positif dari penggunaan LKPD yang dikembangkan. Hal tersebut sesuai dengan pendapat Ambarwati, dkk. (2016) yang menyatakan bahwa penggunaan media pembelajaran di kelas dapat menunjukkan dampak positif, yaitu pembelajaran bisa lebih menarik dan meningkatnya sikap positif peserta didik terhadap apa yang mereka pelajari dalam proses pembelajaran.

LKPD berbasis discovery learning pada materi fluida dinamis sangat bermanfaat dengan skor kemanfaatan 3,36, pada LKPD terdapat tuntunan melakukan kegiatan percobaan dan pertanyaan-pertanyaan diskusi yang bermanfaat bagi peserta didik untuk lebih termotivasi sehingga peserta didik akan memperhatikan pelajaran dan mengikuti pembelajaran secara aktif. LKPD berbasis discovery learning yang dikembangkan mempermudah peserta didik mempelajari materi.

LKPD berbasis discovery learning pada materi fluida dinamis sangat mudah digunakan dengan skor kemudahgunaan 3,30. LKPD yang dikembangkan sangat mudah digunakan karena memiliki bahasa, alur penyajian, petunjuk, paparan orientasi masalah, dan pertanyaan yang jelas, sehingga peserta didik mengerti apa yang harus mereka lakukan selama proses pembelajaran. Kemudahan tersebut membantu guru untuk tidak melakukan penjelasan secara berulang.

Penggunaan LKPD berbasis discovery learning pada materi fluida dinamis dalam pembelajaran di sekolah, LKPD teruji efektif meningkatkan hasil belajar peserta didik. Hasil uji menun- 
jukkan bahwa keefektifan LKPD berbasis discovery learning yang digunakan dalam pembelajaran materi fluida dinamis mencapai $75,68 \%$ peserta didik mendapatkan peningkatan hasil belajar dengan kategori sedang hingga tinggi. Seperti terlihat pada gambar 1.

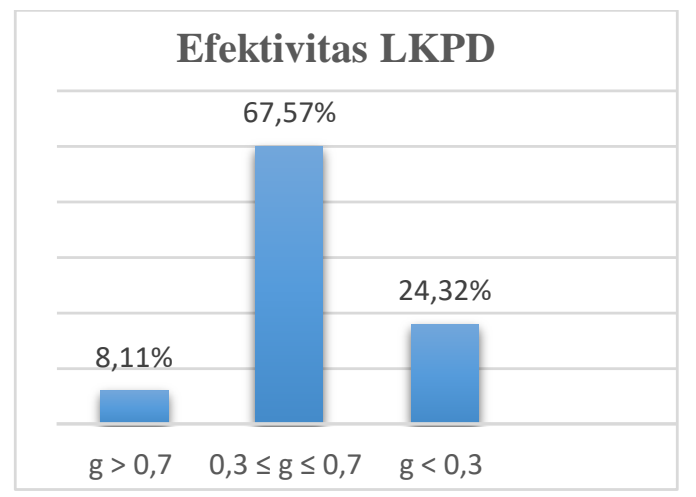

Gambar 1. Hasil Uji Keefektifan LKPD

Peningkatan hasil belajar peserta didik karena pembelajaran didukung oleh keunggulan-keunggulan LKPD berbasis discovery learning yang dikembangkan diantaranya membuat peserta didik terlibat aktif dalam pembelajaran melalui kegiatan langsung seperti percobaan, sehingga peserta didik menjadi terlatih untuk melakukan penemuan dan memungkinkan untuk lebih banyak mengeksplorasi informasiinformasi dari berbagai sumber belajar, selain itu LKPD ini dapat digunakan secara mandiri oleh peserta didik, karena arahan kegiatan atau tugas yang harus dilakukan peserta didik jelas dan menimbulkan kerjasama dan interaksi antar peserta didik. Temuan tersebut juga relevan dengan penelitian Saputro dkk. (2015) yang menunjukkan adanya peningkatan hasil belajar peserta didik SMA dengan penerapan perangkat pembelajaran fisika model discovery learning.

Adapun sebanyak 24,32 \% peserta didik termasuk dalam kategori peningkatan rendah, hal ini dikarenakan sebagian peserta didik masih belum memberikan kontribusi lebih pada kelompoknya selama pembelajaran atau bersifat pasif, selain itu juga adanya perbedaan kemampuan peserta didik dalam memahami materi, sehingga beberapa peserta didik belum bias menyelesaikan permasalahan. Beberapa peserta didik yang termasuk dalam kategori tersebut juga memiliki tingkat kehadiran yang minim saat pembelajaran, sehingga peserta didik tidak mengikuti aktivitas pembelajaran secara langsung.

Temuan tersebut menunjukkan bahwa dalam pembelajaran discovery peserta didik yang memiliki sifat pasif harus dikelompokkan dengan peserta didik yang memiliki sifat aktif dan peserta didik yang memiliki tingkat kecerdasan rendah dikelompokkan dengan peserta didik yang memiliki tingkat kecerdasan tinggi, agar peserta didik secara kolaborasi mampu menyelesaikan permasalahan dengan baik dan dapat bersosialisasi dengan teman yang lainnya. Selain itu, selama pembelajaran pembelajaran menggunakan LKPD berbasis discovery learning pada materi fluida dinamis, harus ada bimbingan dari guru agar peserta didik tetap kondusif dan fokus untuk dapat merumuskan dan memecahkan suatu permasalahan terkait materi, supaya tujuan pembelajaran dapat tercapai.

\section{SIMPULAN}

Simpulan yang didapatkan dari penelitian meliputi: (1) Telah dihasilkan LKPD berbasis discovery learning pada materi fluida dinamis yang tervalidasi dengan kriteria sangat baik; (2) LKPD berbasis discovery learning pada materi fluida dinamis menarik, sangat bermanfaat, dan sangat mudah digunakan; (3) LKPD berbasis discovery learning pada materi fluida dinamis ini efektif digunakan sebagai media pembelajaran. 


\section{DAFTAR RUJUKAN}

Ambarwati, D., Nyeneng, I D. P., dan Suana, W. 2016. Pengembangan LKS Model Inkuiri Terbimbing Berbasis Pendekatan Kontekstual Materi Gaya dan Penerapannya. Jurnal Pembelajaran Fisika. 4(2): 47-58.

Gumrowi, A. 2016. Meningkatkan Hasil Belajar Listrik Dinamik menggunakan Strategi Pembelajaran Team Assisted Individualization melalui Simulasi Crocodile Physisc. Jurnal Ilmiah Pendidikan Fisika Al-Biruni. 5(1): 105-111.

Irmayani, S., Nyeneng, I D. P., dan Viyanti. 2014. Pengaruh Keterampilan Metakognisi terhadap Minat dan Hasil Belajar melalui Metode Pembelajaran Discovery. Jurnal Pembelajaran Fisika. 2(3): 119-130.

Johar, A., Risdianto, E., dan Indriyati, D. A. F. 2014. Perancangan dan Implementasi Media Pembelajaran Berbasis Web Pada Bidang Studi Bahasa Inggris di Kelas VII SMP Negeri 1 Kota Bengkulu dengan Menggunakan Php dan Mysql. Jurnal Rekursif. 2(1): 1-9.

Katriani, L. 2014. Pengembangan Lembar Kerja Peserta Didik (LKPD). Makalah disajikan dalam pelatihan pembuatan perencanaan pembelajaran IPA untuk kegiatan KBM di kelas sebagai implementasi kurikulum 2013 bagi guru SMP di kecamatan Danurejan kota Yogyakarta tanggal 24 Oktober 2014.

Kemendikbud. 2013. Kerangka Dasar Kurikulum 2013. Jakarta: Kementerian Pendidikan dan Kebudayaan.

Kemendikbud. 2016. Silabus Fisika Kelas XI Kurikulum 2013 Revisi
2016. Jakarta: Kementerian Pendidikan dan Kebudayaan.

Khoiriyah, N., Suyatna, A., dan Nyeneng, I D. P. 2013. Pengembangan Lembar Kerja Siswa (LKS) Fisika Berbasis Penemuan Terbimbing Berbantuan Simulasi Komputer. Jurnal Pembelajaran Fisika. 1(6): 115127.

Kusdiningsih, E. Z., Abdurrahman, dan Jalmo, T. 2016. Penerapan LKPD Berbasis Kemampuan Argumentasi-SWH untuk Meningkatkan Kemampuan Argumentasi Tertulis dan Literasi Sains Siswa. Jurnal Pendidikan Progresif. 6(2): 101-110.

Mayasari, H., Syamsurizal, dan Maison. 2015. Pengembangan Lembar Kerja Siswa (LKS) Berbasis Karakter melalui Pendekatan Saintifik pada Materi Fluida Statik untuk Sekolah Menengah Atas. Jurnal Edu-Sains. 4(2): 30-36.

Naz, A., A. dan Akbar, R., A. 2008. Use of Media for Effective Instruction its Importance: Some Consideration. Journal of Elementary Education. 18(1)3540.

Rahmawati, Widodo, W., dan Prabowo. 2012. Pengembangan Perangkat Pembelajaran dengan Metode Pembelajaran Penemuan Terbimbing (Guided Discovery Learning) untuk Melatih Keterampilan Berpikir Kritis dan Penguasaan Konsep pada Siswa SMP. Jurnal Pendidikan Sains Pascasarjana Universitas Negeri Surabaya. 1(2): 68-73.

Saputro, R. P., Wasis, dan Koestiari, T. 2015. Pengembangan Perangkat Pembelajaran Fisika Model Discovery Learning untuk Meningkatkan Hasil Belajar dan 
Keterampilan Berpikir Kreatif. Jurnal Penelitian Pendidikan Sains. 5(1): 693-702.

Sari, P. I., dan Harjono, A. 2016.

Penggunaan Discovery Learning

Berbantuan Laboratorium Virtual pada Penguasaan Konsep Fisika Siswa. Jurnal Pendidikan Fisika dan Teknologi. 2(4): 176-182.

Sintia, R., Abdurrahman, dan Wahyudi, I. 2015. Pengembangan LKS Model Discovery Learning melalui Pendekatan Saintifik Materi Suhu dan Kalor. Jurnal Pembelajaran Fisika Universitas Lampung. 3(2): 125-134.

Sirait, M. 2017. Model Pembelajaran Berbasis Discovery-Inkuiri dan Kontribusinya terhadap Penguatan Kualitas Pembelajaran. Jurnal Pendidikan Dasar. 1(2): 155-170.

Suradnya, L. S. A., Suyanto, E., dan Suana, W. 2016. Modul Interaktif dengan Program LCDS untuk Materi Cahaya dan Alat Optik. Jurnal Pembelajaran Fisika. 4(2): 35-46.

Suyanto, E., dan Sartinem. 2009. Pengembangan Contoh Lembar Kerja Fisika Siswa dengan Latar Penuntasan Bekal Awal Ajar Tugas Studi Pustaka dan Keterampilan Proses untuk SMA Negeri 3 Bandar Lampung. Prosiding Seminar Nasional Pendidikan 2009. ISBN: 978-979-18755-1-6. Universitas Lampung: Bandar Lampung.

Suyanto, S., Paidi, dan Wilujeng, I. 2011. Lembar Kerja Siswa (LKS).
Makalah disajikan dalam Pembekalan guru daerah terdepan, terluar, dan tertinggal di Akademi Angkatan Udara Yogyakarta tanggal 26 November-6 Desember 2011.

Wahjudi, E. 2015. Penerapan Discovery Learning Dalam Pembelajaran IPA Sebagai Upaya Untuk Meningkatkan Hasil Belajar Siswa Kelas Ix-I. Jurnal Lentera Sains. 5(1): 1-16.

Wahyudi dan Siswanti, M. C. 2015. Pengaruh Pendekatan Saintifik melalui Model Discovery Learning dengan Permainan terhadap Hasil Belajar Matematika Siswa Kelas 5 SD. Jurnal Scholaria. 5(3): 23-36.

Wahyuni, N. dan Maureen, I. Y. 2010. Pemanfaatan Media Puzzle Metamorfosis dalam Pembelajaran Sains untuk Meningkatkan Hasil Belajar Siswa Kelas II SDN Sawunggaling I/382 Surabaya. hajul.Jurnal Mahasiswa Teknologi Pendidikan. 1(2).

Widjajanti, E. 2008. Kualitas Lembar Kerja Siswa. Makalah Seminar Pelatihan penyusunan LKS untuk Guru SMK/MAK pada Kegiatan Pengabdian Kepada Masyarakat Jurusan Pendidikan FMIPA.

Wijayanti, D. 2016. Pengembangan perangkat pembelajaran statistika dan peluang dengan metode penemuan terbimbing berorientasi Kurikulum 2013 untuk siswa kelas X. Jurnal Riset Pendidikan Matematika. 3(1): 23-33. 